\title{
Ecosystem-level effects of large-scale disturbance in kelp forests
}

\author{
K. M. Norderhaug ${ }^{1,2, *}$, K. Filbee-Dexter ${ }^{1,3}$, C. Freitas ${ }^{1,4}$, S.-R. Birkely ${ }^{5}$, \\ L. Christensen ${ }^{1}$, I. Mellerud ${ }^{1}$, J. Thormar ${ }^{1}$, T. van Son $^{1}$, F. Moy ${ }^{1}$, M. Vázquez Alonso ${ }^{1}$, \\ H. Steen ${ }^{1}$
}

\author{
${ }^{1}$ Institute of Marine Research (IMR), Nye Flødevigen vei 20, 4817 His, Norway \\ ${ }^{2}$ University of Oslo, Department of Biosciences, PO Box 1066 Blindern, 0316 Oslo, Norway \\ ${ }^{3}$ University of Western Australia, School of Biological Sciences, 35 Stirling Hwy, Perth, WA 6009, Australia \\ ${ }^{4}$ Marine and Environmental Sciences Center, Madeira Tecnopolo, 9020-105 Funchal, Portugal \\ ${ }^{5}$ Institute of Marine Research (IMR), Hjalmar Johansens Gate 14, 9294 Tromsø, Norway
}

\begin{abstract}
Understanding the effects of ecological disturbances in coastal habitats is crucial and timely as these are anticipated to increase in intensity and frequency in the future due to increasing human pressure. In this study we used directed kelp trawling as a scientific tool to quantify the impacts of broad-scale disturbance on community structure and function. We tested the ecosystem-wide effects of this disturbance in a BACI design using two $15 \mathrm{~km}^{2}$ areas. The disturbance had a substantial impact on the kelp forests in this study, removing 2986 tons of kelp and causing a $26 \%$ loss of total kelp canopy at trawled stations. This loss created a $67 \%$ reduction of epiphytes, an $89 \%$ reduction of invertebrates and altered the fish populations living within these habitats. The effect of habitat loss on fish was variable and depended on how the different species used the habitat structure. Our results show that large-scale experimental disturbances on habitat-forming species have ecological consequences that extend beyond the decline of the single species to affect multiple trophic levels of the broader ecosystem. Our findings have relevance for understanding how increasing anthropogenic disturbances, including kelp trawling and increased storm frequency caused by climate change, may alter ecosystem structure and function.
\end{abstract}

KEY WORDS: Laminaria hyperborea $\cdot$ Habitat loss $\cdot$ Community structure $\cdot$ Kelp trawling

\section{INTRODUCTION}

The scale, frequency and intensity of ecological disturbances are increasing with climate change (Turner 2010, Seidl et al. 2016). At the same time, direct human use, such as harvest and fishing, are intensifying and are disturbing many marine ecosystems, reducing their resilience (Filbee-Dexter \& Scheibling 2014, Ling et al. 2015). As a result, it is increasingly critical to understand the community and ecosystem-level impacts of disturbances in marine ecosystems. Kelp forests are highly productive

${ }^{*}$ Corresponding author: kjellmn@hi.no

$\S$ Advance View was available online September 24, 2020 and diverse marine ecosystems that extend along temperate and polar coasts (Wernberg et al. 2019). Recent human-driven changes in our oceans are impacting and destabilizing kelps forests at global scales, causing large-scale losses of kelp in many regions (Krumhansl et al. 2016, Wernberg et al. 2019). These impacts include kelp harvesting (Vásquez 2008), acute and chronic warming (Wernberg et al. 2016, Smale 2020), unusually cold periods (Norderhaug et al. 2015), storms (Filbee-Dexter \& Scheibling 2012) and overgrazing (Ling et al. 2015). Harvesting and commercial use of seaweed is a rapidly expand-

(C) The authors 2020. Open Access under Creative Commons by Attribution Licence. Use, distribution and reproduction are unrestricted. Authors and original publication must be credited. 
ing industry providing products such as alginate, fertilizers, agricultural feed and pharmaceuticals, and wild harvesting of kelp forests is intensifying in many regions (Buschmann \& Camus 2019). Kelp forests are also ecologically valuable habitats. As foundation species, kelps create 3-dimensional habitats, which provide food for numerous species and modify the local environment to support distinct communities of plants and fish and invertebrates (Norderhaug et al. 2002, 2015, Teagle et al. 2017). Therefore, understanding impacts from ecological disturbances on kelps are particularly important because they may affect higher trophic levels that rely on these habitats. The impacts on associated communities and the recovery trajectory of the habitat should be shaped by both the spatial extent and intensity of ecological disturbance (Dudgeon \& Petraitis 2001, Wernberg \& Connell 2008). Yet, the consequences of spatially extensive disturbances in kelp forests are largely unknown and rarely tested experimentally. Such knowledge is essential to understand the role of kelp as foundation species, the broader implications of disturbance events and for sustainable management of kelp resources.

Manipulative experiments are powerful tools to study and test hypotheses on ecological processes. To date, experimental disturbances in kelp forests have been restricted to small-scale (meters) canopy clearings (e.g. $1.4 \mathrm{~m}^{2}$, Kennelly \& Underwood 1993; 4-15 m², Dayton et al. 1984; $1256 \mathrm{~m}^{2}$, Clark et al. 2004; $7 \mathrm{~m}^{2}$, Wernberg \& Connell 2008). Exceptions are 'large-scale removal' experiments of Macrocystis pyrifera kelp forests in California and Nereocystis luetkeana in Alaska, but even these only covered $0.1 \mathrm{~km}^{2}$ (Bodkin 1988) and $1500 \mathrm{~m}^{2}$ (Siddon et al. 2008), respectively. The NE Atlantic is understudied and experiments on a large scale remain scarce (Smale et al. 2013). Therefore, there is a mismatch between the scale of localized experiments and the seascape structure of kelp forests, which can extend over hundreds to thousands of meters. As a result, experiments measuring the ecological impacts of kelp loss are generally limited to the fauna that use the habitat on these smaller scales (e.g. epiphytes, mesograzers), and do not capture impacts on the fauna that use the habitat on broad scales, such as large fish.

In this study, we used directed kelp trawling, a human activity that physically removes large quantities of kelp at scales of hundreds of meters using a bottom sledge (Vea \& Ask 2011), as a scientific tool to quantify the impacts of broad-scale disturbance on community structure and function in kelp forest ecosystems. Quantitative data describing provision and loss of ecosystem functions and services in kelp forests are typically hard to obtain and compare, and are therefore generally deficient (Bennett et al. 2015). Although a number of studies have shown how macroalgal and invertebrate communities respond to small-scale disturbances, fewer studies have been devoted to highly mobile fish and other species operating on larger scales (tens to hundreds of meters). An important reason for this is different catchability and visibility of fish assemblages in dense vegetation compared to open areas (e.g. continental shelf) (Duffy et al. 2019). To overcome such methodological challenges, we used new acoustic and visual methods in combination with traditional fishing methods. To our knowledge, ours is the first study focusing on benthic community response to experimental disturbance on such a large scale, and we therefore placed emphasis on responses in demersal fish assemblages that use these habitats on multiple scales. Specifically, we wanted to test how a large-scale directed kelp trawling affected: (1) the habitat structure of the kelp forest, (2) the available secondary habitat created by epiphytic algae on kelp stipes, (3) densities of invertebrates associated to epiphytes, (4) assemblages of fish associated with kelp, and (5) the use of kelp forests as nursery habitat for coastal fish (i.e. abundance of juvenile fish).

\section{MATERIALS AND METHODS}

\subsection{Study area and design}

The study was performed in the archipelago outside Vikna, Norway $\left(64^{\circ} 47^{\prime} \mathrm{N}, 10^{\circ} 31^{\prime} \mathrm{E}\right.$; Fig. 1$)$, which is a collection of shoals and islands that support extensive Laminaria hyperborea kelp forests (Fig. 2A). We defined 2 equally sized 'kelp forest areas' as polygons in GIS: one control area and one area that we opened for trawling. Both study areas are $\sim 15 \mathrm{~km}^{2}$ island groups that have comparable depth, topography and position, suggesting comparable environmental conditions (e.g. wave exposure levels). Although parts of the archipelago had been subjected to kelp trawling trials in the past, neither of the 2 areas had been trawled for at least 4 yr prior to the study.

This study was a collaboration with the Norwegian kelp harvest industry and resource managers (The Norwegian Directorate of Fisheries) designed to test the ecological impacts of kelp trawling, to provide advice on possible opening of an area that is closed for kelp trawling, and to assess the sustainability of 


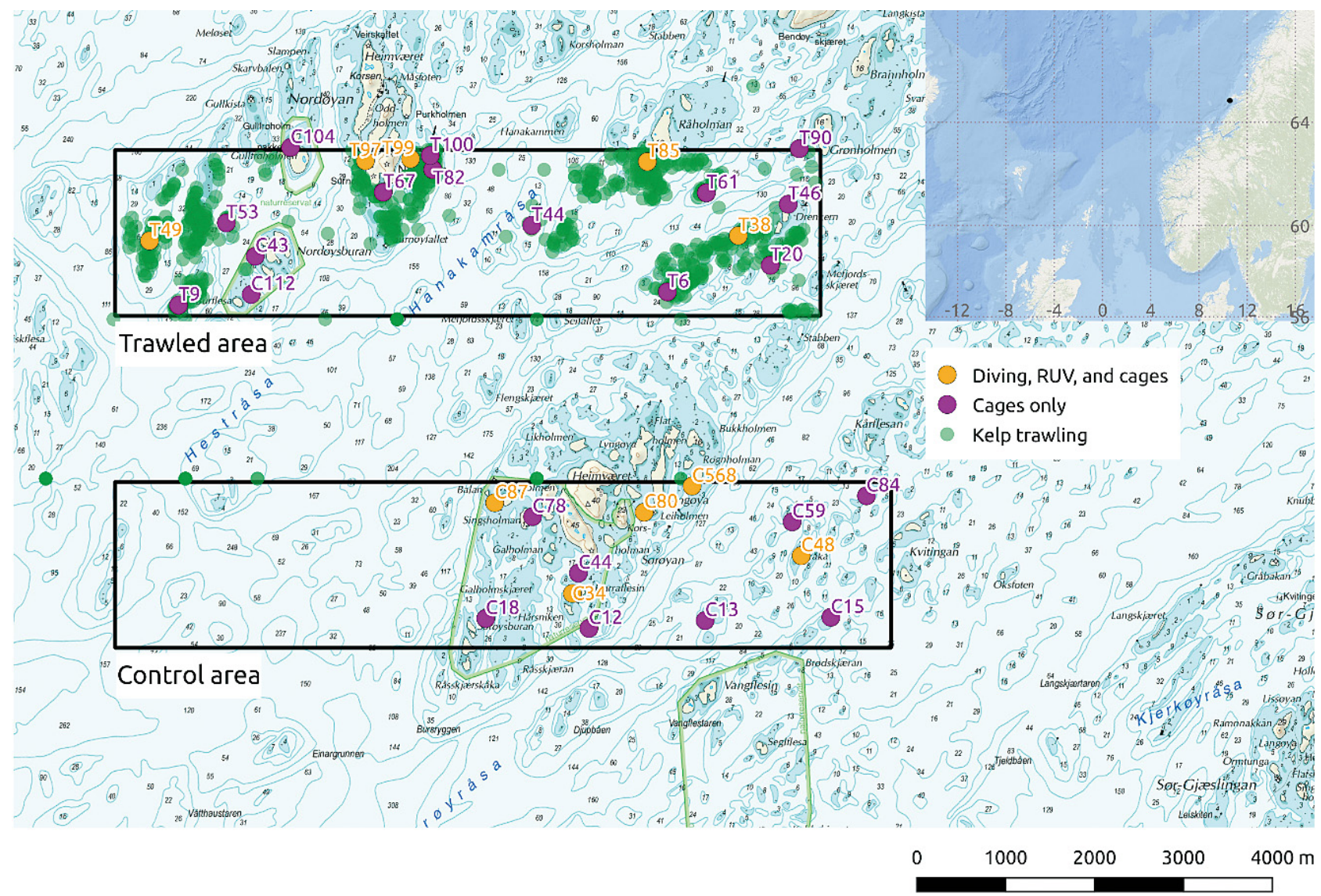

Fig. 1. Map of the study area, showing the 10 dive stations (diving, RUV and cages) and the additional 22 fish stations (cages only) in the impact and control areas. Note that 3 of the fish stations in the impact area were placed in seabird reserves, where kelp trawling was not performed, and served as control stations (C) inside the impact area

the industry. We used a controlled BACI (before-after, control-impact) design, to minimize the extent of unwanted effects outside the focus of the study and to comply with the issued permits for harvest. The impacted area was situated in the northern part of the archipelago and the control area in the southern part, with 2 small reserves in the northern area also used as controls (Fig. 1). The impacted and control areas were restricted to depths ranging between 5 and $20 \mathrm{~m}$. Sites were selected within each area using a random stratified selection, stratifying on 3 levels of wave exposure: low $(<0.6 \mathrm{~m}$ significant wave height), intermediate (between 0.6 and $0.9 \mathrm{~m}$ ) and high ( $>0.9 \mathrm{~m} ;$ Fig. 1). Three of the sites in the impact area were inside seabird reserves that were not trawled and were used therefore as control sites. A total of 16 sites were used as trawl stations and 16 as control stations (13 of these in the control area and 3 in the impact area; Table 1). At all selected sites we conducted drop camera transects to measure trawling intensity and used cages to catch fish and crabs
(Table 1). At 11 of these sites, divers swam transects to measure trawling intensity, sampled kelp, associated algae and invertebrates, and performed acoustic and visual measures. All sampling procedures are described below.

\subsection{Kelp trawling}

Field sampling was performed before (September 2017) and after (September 2018) controlled kelp trawling. In May 2018, kelp was removed from the impacted area by commercial kelp trawlers, creating large open clearings along the reefs at the sampling stations (Fig. 2C). The study area was then left to settle until the after-assessment 4 mo later. This avoided capturing initial trawling effects, e.g. attraction of fish to prey exposed by the trawling activity. Kelp trawling was performed by vessels dragging a pronged $3 \mathrm{~m}$ wide bottom sledge designed to hook kelp. The vessels operated at 3-20 m depth. The sledge cre- 

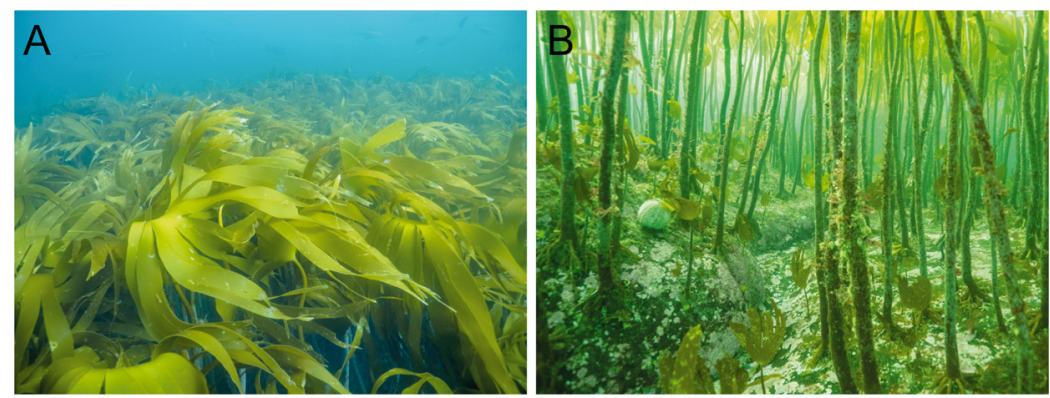

percent kelp canopy cover in these videos was quantified from frame grabs and used to compare disturbance intensity before and after kelp trawling and between trawled and untrawled stations.
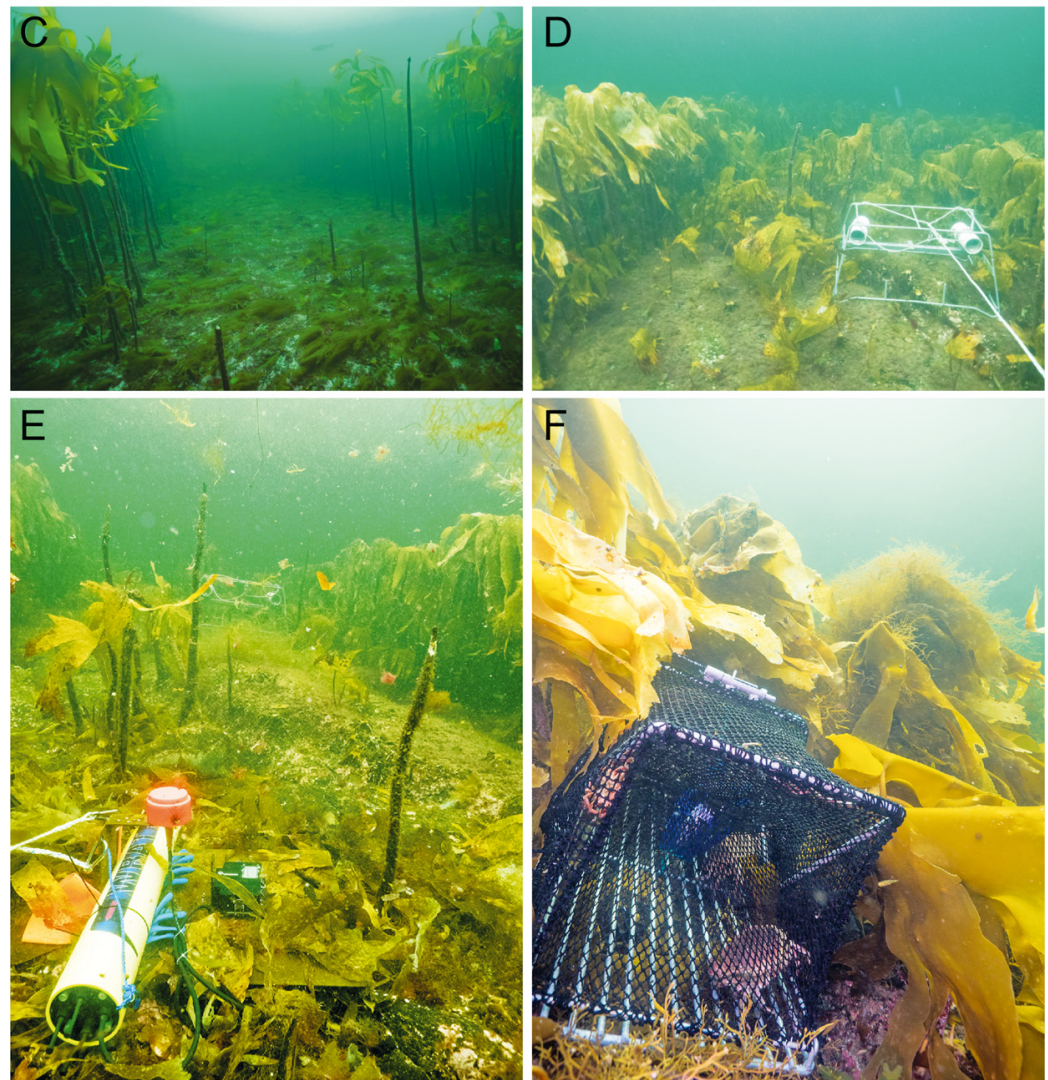

Fig. 2. (A) Pristine kelp forest, (B) kelp stipes with epiphytes under the canopy, (C) trawl track through dense kelp forest, (D) remote underwater video (RUV),

(E) WBAT echosounder and (F) fish cage used in the study

\subsection{Primary and secondary producers}

Kelp density and size was measured in both areas and before and after kelp trawling by SCUBA divers sampling all kelps in 4 replicate and haphazardly placed $0.5 \times 0.5 \mathrm{~m}$ quadrats in each site. Kelp age, stipe length and weight, lamina length and weight, holdfast weight and size, and total epiphyte weight were measured for each individual kelp. The age of kelps was estimated by counting cortical growth zones (Steen et al. 2016). An additional 3 kelps from each station were sampled in cotton bags to prevent mobile invertebrates from escaping. Epiphytic algae on kelp stipes (Fig. 2B) are the most important microhabitat for numerous amphipods, gastropods and other invertebrates, which are the main prey species for most kelpassociated fish (Norderhaug et al. 2005, 2007). All animals were rinsed out from the epiphytes using freshwater through a $500 \mu \mathrm{m}$ sieve and stored in plastic bottles. At the laboratory, they were identified and counted through a dissecting microscope and weighed (in $\mathrm{g}$ wet weight).

ated $3 \mathrm{~m}$ wide and up to 100s of $\mathrm{m}$ long openings in the kelp forest when removing canopy kelps.

\subsection{Disturbance intensity}

Disturbance intensity was assessed at all sites before and after kelp trawling using a submersible video camera (drop camera) deployed from a fishing vessel along a $50 \mathrm{~m}$ long transect (one transect per cage station). In addition, in 11 of the sites, scuba divers swam a $50 \mathrm{~m}$ dive transect using a PARALENZ (www.paralenz.com) video camera facing downwards with 1080 pixel resolution (one transect per dive station). The

\subsection{Fish assemblages associated with the kelp forest}

\subsubsection{Acoustics and WBAT}

Bottom-mounted, upward-facing echosounders were used to measure fish densities in the water column above the kelp canopy. The SIMRAD Wideband Autonomous Transceiver (WBAT, simrad.com; Fig. 2E) is autonomous and constructed to reduce noise. Two WBATs with $200 \mathrm{kHz}$ transducers were used to compare fish densities in the water column above trawled and untrawled kelp forest at night (from 20:00 to 08:00 $\mathrm{h}$ local time), when fish are expected to be most active. In 2017 (the first year), 2 EK15 with $200 \mathrm{kHz}$ 
Table 1. Sampling devices used at stations in the trawled and control areas. At dive stations, kelp cover was measured by diver transects, and kelps and the associated communities of algae and invertebrate fauna were sampled. Bottom-mounted echosounders (WBAT) and remote underwater video rigs (RUVs) were used. At cage stations, kelp cover was measured by drop camera transects and fish and crab cages were used. Three stations in the trawled area (C112, C43 and C104) were inside seabird reserves and therefore not trawled. These were used as control stations

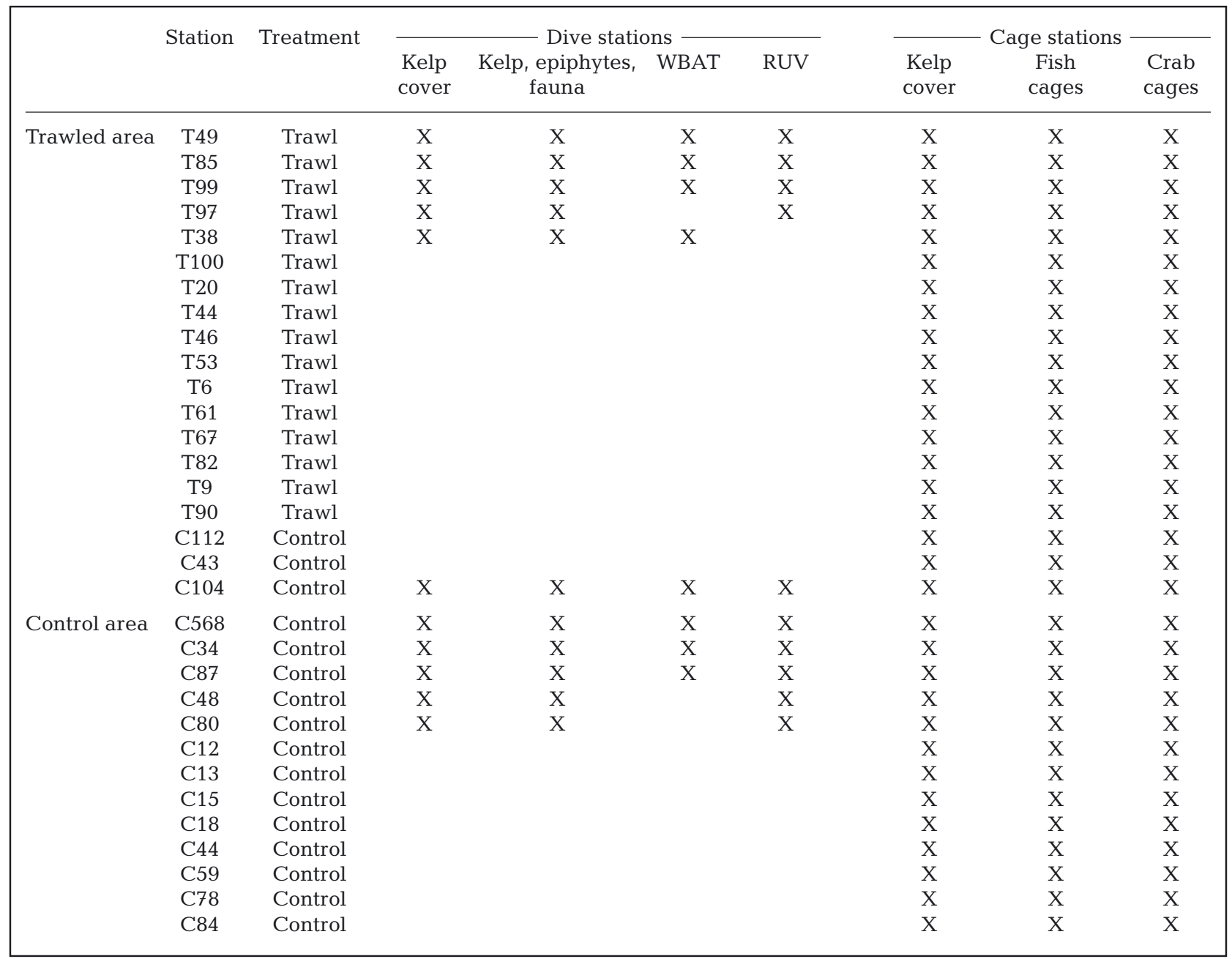

transducers with cable to onshore boxes containing transceiver unit, PC and battery were used. To compare possible differences between data from the 2 systems (e.g. arising from variation in ping rate), one EK15 200 $\mathrm{kHz}$ transducer was used together with the WBAT $200 \mathrm{kHz}$ at one station in the second year. From this, a correction factor of 0.529 was calculated and used for the EK15 counts. In both years, upward-facing GoPro cameras were used together with the echosounders to identify fish from the echograms (during daytime/light only). The echosounders were deployed from a boat and positioned on the seafloor by a diver. The diver arranged a line to a surface float with a weight to keep the line away from the transducer. Total fish densities per square meter were calculated using LSSS (Large Scale Survey System; Korneliussen et al. 2016).

\subsubsection{Fish and crab cages}

Two different types of cages where used for capturing fish and crabs. All cages were baited and therefore caught actively foraging fish searching for food (Fig. 2F). Two-chambered, cylindrical wrasse cages (each baited with $1 / 2$ of a brown crab) were used to catch 10-30 cm large fishes, whereas rectangular crab cages (each baited with $1 / 2$ of a saith) were used to catch crab (Bodvin et al. 2014). Five wrasse cages and 2 crab cages were deployed at 5-10 m depth at each site and hauled the following day. The catches were collected, identified to species, measured for length and weighed, before the cages were rebaited and redeployed at a new station. Each site was only sampled once per year. 


\subsubsection{Remote underwater video}

We used unbaited remote underwater video (RUV; Fig. 2D) to collect data on fish occurring under the kelp canopy, including juvenile fish using the kelp forest as a nursery area. This sampling method does not attract fish and solves the problem of the influence of a diver on fish counts (Langlois et al. 2010). Stereo video provides depth vision and one can thus assess the amount of fish in a defined and limited water volume, thus overcoming the bias of different visibility of fish in dense kelp forest compared to open areas (Perry et al. 2018). Each of our RUV rigs carried 2 camera housings containing a GoPro Hero Black 5 with an extra battery pack for prolonged recordings. Three-dimensional calibration files for each camera pair were constructed using the SeaGIS software Cal (www.seagis.com.au) and the $1 \times 1 \times 0.5 \mathrm{~m}$ sized calibration cube 'Cal'. Videos were used to quantify fish densities and identify species inside trawled and untrawled kelp forests. In untrawled kelp forests, one video rig was placed by a diver on a horizontal surface below the canopy. At the trawled stations, one video rig was placed in the center of the trawl track and one was placed on the track margin facing the surrounding kelp forest to capture edge effects. The rigs were positioned by a diver and the kelps standing immediately in front of the cameras were removed to ensure the field of view was clear. At each station, a minimum of $1 \mathrm{~h}$ and maximum of $5.5 \mathrm{~h}$ of video was recorded during daytime. The difference in recording time was accounted for in analysis (see Section 2.7). Videos were analyzed with EventMeasure (SeaGis) on stereo mode, synchronizing screens from both the right and left cameras to obtain the same frames on the video sequences. All fish observed in the video were identified to species (or highest taxonomic level possible) and their size, position (distance to camera), entrance time and departure time were registered in order to calculate changes in fish density and community structure. The first $10 \mathrm{~min}$ were removed from the videos to remove any influence of disturbance from the divers from the analysis. We used a 1-m visual distance to obtain equal sampling water volume in dense kelp forests and open trawl tracks.

\subsection{Trophic food web structure}

Stomach contents from fish caught in the fish cages (to a maximum of 15 stomachs per species per station) were frozen direct after collection and analyzed under a dissecting microscope later the same day to mini- mize decomposition. Stomach items were identified to species or the lowest taxonomic level possible. Fragments of prey were collected to estimate prey numbers as accurately as possible. Most of the collected stomachs were empty. Therefore, the data collected were suitable for identifying prey of different fish, which was used to infer feeding behavior, confirm which species were preying on kelp-associated fauna and calculate trophic level, but were not suitable for analyzing differences between areas and effects from trawling.

\subsection{Statistical analyses}

Generalized linear mixed models (GLMMs) were used to quantify the effect of trawling on kelp, epiphyte and fish communities. Models were fitted to the following response variables: percentage kelp cover, number of kelp plants per $\mathrm{m}^{2}$, total kelp biomass per $\mathrm{m}^{2}$, individual kelp length, individual kelp weight, kelp age, epiphyte and invertebrate weight per $\mathrm{m}^{2}$, fish density per $\mathrm{m}^{2}$ (echosounder data), number of fish, number of crabs and number of fish species per site (fish cage data), and number of fish per h (RUV data). Trawling (impact, control) and period (before: 2017, after: 2018) were used as fixed factors, as well as their interaction (the BACI effect). Station was included as a randomeffect variable to account for random variation between stations. Models took the following form:

$$
\begin{gathered}
\text { Response variable }=\alpha+\beta_{1} \text { Trawling }+\beta_{2} \text { Period }+ \\
\beta_{3} \text { Trawling } \times \text { Period }+\alpha+\varepsilon
\end{gathered}
$$

where the term $\alpha$ is the model intercept and $\beta_{1}$ to $\beta_{3}$ are the model coefficients. The random intercept $\alpha$ allows for a random variation around the intercept $\alpha$, and is assumed to be normally distributed with mean 0 and variance $\delta^{2}$. The term $\varepsilon$ is independently normally distributed noise.

The following response variables were fitted using a Gaussian distribution: percentage kelp cover (logit transformed), total kelp biomass per $\mathrm{m}^{2}$, individual kelp length, individual kelp weight, kelp age, epiphyte weight per $\mathrm{m}^{2}$ (log transformed) and fish density per $\mathrm{m}^{2}$. Count response variables were fitted using a Poisson distribution. For RUV data on number of fish per $h$, the number of video hours was entered as an offset in the models. Model validation was performed following Zuur \& Ieno (2016) and indicated that some Poisson models were over-dispersed. These were later fitted with a negative binomial distribution, which solved the over-dispersion issues. Analyses were performed using the packages nlme and lme4 (Bates et 
al. 2015) in the statistical program R (v. 3.5.1; R Core Team 2018).

\section{RESULTS}

\subsection{Disturbance intensity}

A total of 2986 tons of kelp was removed from all the trawl stations (personal communication, Directorate of Fisheries, Norway) and resulted in a significant reduction of total kelp cover in the impacted area from $88.6 \pm 13.5 \%$ (mean $\pm \mathrm{SD}$ ) before trawling to $62.4 \pm 22.0 \%$ after trawling (Fig. 3, Table 2). The resulting kelp matrix post trawl was a mix of patches of remaining kelps and open trawl tracks dominated by scattered young, small understory kelps with little epiphytes, reflected in the high variation in kelp and epiphyte size after trawling. Most kelps removed by trawling detached with the holdfast, and the trawl tracks also showed numerous scars of bare substrate where these holdfasts used to be attached. The kelp cover in the reference area was unchanged at $89.0 \pm 12.5 \%$ in the first year to $89.8 \pm 13.2 \%$ in the second year (Fig. 3, Table 2).

\subsection{Kelp and epiphytic macroalgae}

The direct effect of removing the canopy by trawling was a significant decrease in kelp weight and length and kelp abundance and biomass per $\mathrm{m}^{2}$ (Fig. 3, Table 2). All registered kelps were Laminaria hyperborea.

Epiphytic fouling (measured as the total epiphytic weight per kelp stipe) was highly variable in both areas and years (Fig. 3D). Kelp canopies composed of the largest and oldest kelps had high epiphyte cover, while smaller and younger kelps had low epiphytic cover. Because the number of canopy kelps was reduced after trawling, a reduction of epiphytes from $213 \pm 232$ to $72 \pm 114 \mathrm{~g}$ per $\mathrm{m}^{2}$ was observed in total at trawled stations.

\subsection{Invertebrate fauna}

The invertebrate fauna on the epiphytes were dominated by gastropods (e.g. Ansates pellucida, Lacuna vincta, Rissoa parva) bivalves (e.g. Mytilus edulis, Hiatella arctica), amphipods (e.g. Jassa falcata), isopods (e.g. Idotea granulosa), decapods (e.g. Galathea strigosa), polychaetes (e.g. Nereidae) and echino- derms (e.g. Ophiopholis acuelata). Their abundances and weights roughly correlated to the amount of epiphytes (abundance: $7.54 \pm 4.53 \mathrm{~g}^{-1} \mathrm{WW}$ epiphytic algae with $\mathrm{R}^{2}=0.66$ and $0.23 \pm 0.09 \mathrm{~g}$ WW invertebrates per $g$ WW epiphytic algae with $\mathrm{R}^{2}=0.80$ ). From epiphytic volumes per $\mathrm{m}^{2}$ (Fig. 3D), their weights were shown to be significantly reduced from $31.5 \pm 12.6$ before to $3.4 \pm 1.6 \mathrm{~g} \mathrm{~m}^{-2}$ after trawling (Fig. 4, Table 3).

\subsection{Fish and crabs}

\subsubsection{Echograms}

Echogram counts from WBAT indicated a decrease in the total density of fish above the canopy both in the trawled and the control areas between the first and second year (Fig. 5). There was no significant effect of trawling on fish densities in the water column over the kelp forest (Table 4). Cameras on the echosounders showed that records of fish were mainly schools of small saithe Pollachius virens.

\subsubsection{Fish and crab cages}

Overall, there was no significant reduction after trawling in the total number of fish or in the total number of species per site, but there were significant effects on the species level (Fig. 6, Table 5). The number of goldsinny wrasse Ctneolabrus rupestris was significantly reduced by trawling, while its abundance increased in the control area from the first to the second year. Few cod were caught overall, and this could be the reason why no significant effect from trawling or between years was found. The catches of saithe (mainly small fish) in fish and crab cages were lower in both areas in the second year compared to the first, but this difference was larger in the reference area, so there was consequently a significantly positive effect of trawling on the number of saithe caught per site (Table 5). In total, more crabs and less fish were caught the second year compared to the first year in both areas.

\subsubsection{RUV trawl tracks and kelp margins versus control}

The RUVs measured a significant decrease in the total number of fish per hour in the trawled area both in the trawl tracks (from $118 \pm 132$ to $64 \pm 71$ ind. $\mathrm{h}^{-1}$ ) and an even larger reduction along the kelp margins 

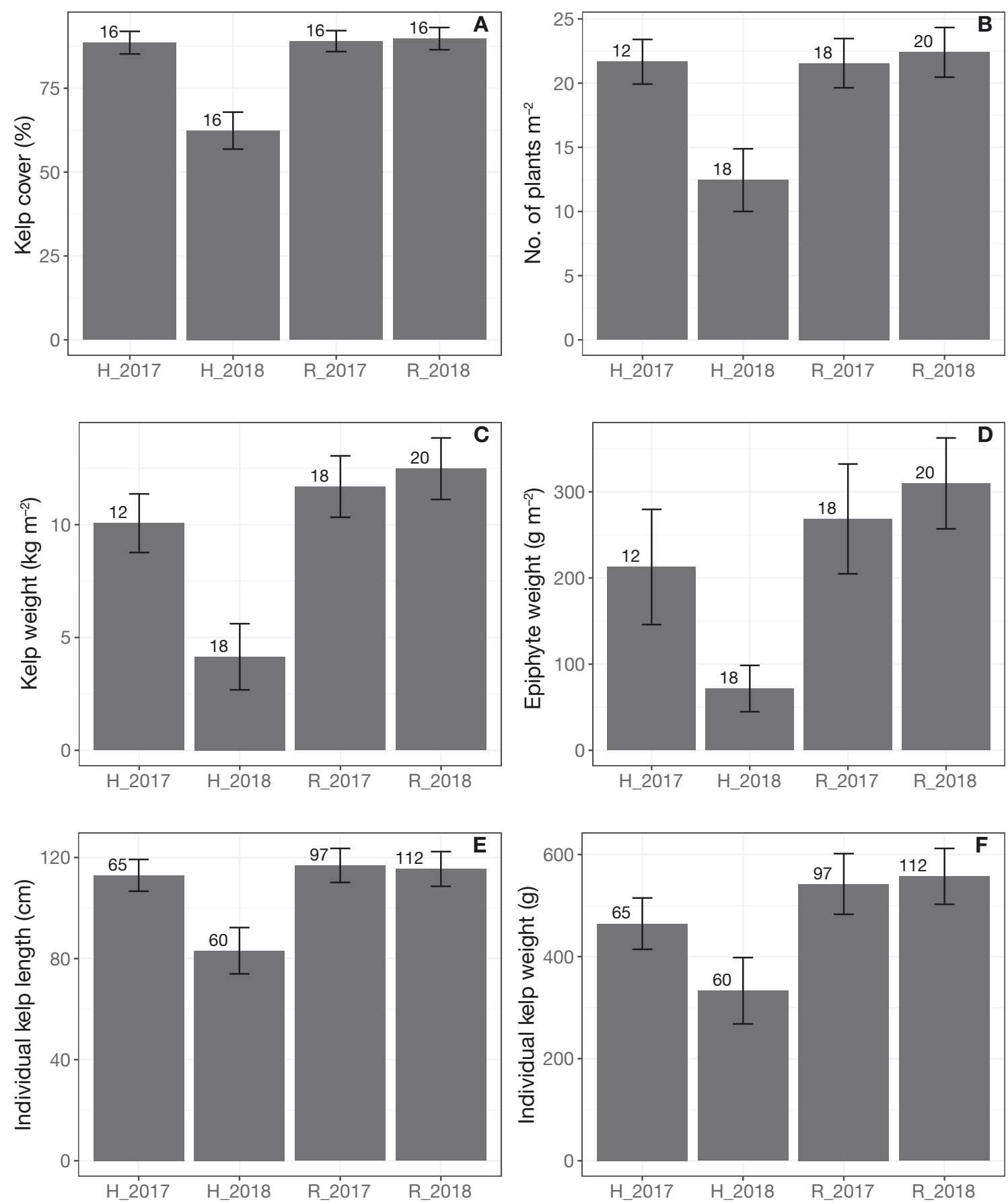

Fig. 3. (A) Average kelp cover (\%) along $50 \mathrm{~m}$ dive and drop-camera transects, $(\mathrm{B}, \mathrm{C})$ average kelp density and biomass per $\mathrm{m}^{2}$, (D) average biomass of epiphytes per $\mathrm{m}^{2}$ and $(\mathrm{E}, \mathrm{F})$ average length and weight of individual kelp in $0.5 \times 0.5 \mathrm{~m}$ quadrats in trawled (harvested $[\mathrm{H}]$ ) and control (reference [R]) stations before and after kelp trawling. Error bars are \pm SE; number of replicates is given above bars

(to $12 \pm 10$ ind. $\mathrm{h}^{-1}$; Fig. 7, Table 6). On the species level, a large reduction in the number of goldsinny wrasse after trawling was observed, but few wrasses were identified in the control area both before and after trawling and this reduction was only significant in the kelp margins (Table 6). Goldsinny wrasse were not very mobile and were closely associated with individual kelps in the video. The total number of observed cod was small (a total of $60 \mathrm{cod}$ ) and the model did not converge. A significant reduction 
Table 2. Results from generalized linear mixed models comparing kelp cover, number and biomass of kelp per $\mathrm{m}^{2}$, biomass of epiphytes per $\mathrm{m}^{2}$, as well as length, weight and age of individual kelp in the control and trawled areas before (September 2017) and after (September 2018) kelp trawling. Model coefficients ( $\beta$ ), standard error (SE), degrees of freedom $(\mathrm{DF}), t$ (Gaussian distribution models), $z$ (negative binomial model), p-values and model distribution are shown. Significance on a 0.05 level is indicated by bold text

\begin{tabular}{|c|c|c|c|c|c|c|}
\hline Response variable & Term & $\beta$ & $\mathrm{SE}(\beta)$ & $\mathrm{DF}$ & $t / z$ & $\mathrm{p}$ \\
\hline $\begin{array}{l}\text { Kelp cover }(\%) \\
\text { (logit transformed) }\end{array}$ & $\begin{array}{l}\text { Intercept } \\
\text { Trawling[Impact] } \\
\text { Period[After] } \\
\text { Trawling } \times \text { Period }\end{array}$ & $\begin{array}{r}2.83 \\
0.33 \\
0.49 \\
-3.05\end{array}$ & $\begin{array}{l}0.49 \\
0.69 \\
0.62 \\
0.88\end{array}$ & $\begin{array}{l}30 \\
30 \\
30 \\
30\end{array}$ & $\begin{array}{r}5.82 \\
0.47 \\
0.80 \\
-3.47\end{array}$ & $\begin{array}{c}<\mathbf{0 . 0 0 1} \\
0.64 \\
0.43 \\
\mathbf{0 . 0 0 2}\end{array}$ \\
\hline No. of kelp plants $\mathrm{m}^{-2}$ & $\begin{array}{l}\text { Intercept } \\
\text { Trawling[Impact] } \\
\text { Period[After] } \\
\text { Trawling } \times \text { Period }\end{array}$ & $\begin{array}{r}3.05 \\
0.08 \\
0.03 \\
-0.68\end{array}$ & $\begin{array}{l}0.14 \\
0.22 \\
0.16 \\
0.25\end{array}$ & & $\begin{array}{r}22.529 \\
0.372 \\
0.213 \\
-2.723\end{array}$ & $\begin{array}{c}<\mathbf{0 . 0 0 1} \\
0.71 \\
0.83 \\
\mathbf{0 . 0 1}\end{array}$ \\
\hline Kelp weight $\left(\mathrm{g} \mathrm{m}^{-2}\right)$ & $\begin{array}{l}\text { Intercept } \\
\text { Trawling[Impact] } \\
\text { Period[After] } \\
\text { Trawling } \times \text { Period }\end{array}$ & $\begin{array}{r}11.69 \\
-0.44 \\
1.11 \\
-8.35\end{array}$ & $\begin{array}{l}1.71 \\
2.67 \\
1.74 \\
2.67\end{array}$ & $\begin{array}{c}55 \\
9 \\
55 \\
55\end{array}$ & $\begin{array}{r}6.82 \\
-0.17 \\
0.64 \\
-3.13\end{array}$ & $\begin{array}{c}<\mathbf{0 . 0 0 1} \\
0.87 \\
0.53 \\
\mathbf{0 . 0 0 3}\end{array}$ \\
\hline $\begin{array}{l}\text { Epiphyte weight } \mathrm{m}^{-2} \\
\left(g_{;} \text {log transformed) }\right.\end{array}$ & $\begin{array}{l}\text { Intercept } \\
\text { Trawling[Impact] } \\
\text { Period[After] } \\
\text { Trawling } \times \text { Period }\end{array}$ & $\begin{array}{r}5.14 \\
0.03 \\
0.32 \\
-8.22\end{array}$ & $\begin{array}{l}1.02 \\
1.60 \\
1.12 \\
1.71\end{array}$ & $\begin{array}{c}55 \\
9 \\
55 \\
55\end{array}$ & $\begin{array}{r}5.03 \\
0.02 \\
0.28 \\
-4.80\end{array}$ & $\begin{array}{c}<\mathbf{0 . 0 0 1} \\
0.98 \\
0.78 \\
<\mathbf{0 . 0 0 1}\end{array}$ \\
\hline Kelp length (cm) & $\begin{array}{l}\text { Intercept } \\
\text { Trawling[Impact] } \\
\text { Period[After] } \\
\text { Trawling } \times \text { Period }\end{array}$ & $\begin{array}{r}120.42 \\
2.68 \\
-0.08 \\
-45.01\end{array}$ & $\begin{array}{r}11.51 \\
17.64 \\
9.10 \\
15.76\end{array}$ & $\begin{array}{c}317 \\
9 \\
317 \\
317\end{array}$ & $\begin{array}{r}10.46 \\
0.15 \\
-0.01 \\
-2.86\end{array}$ & $\begin{array}{c}<\mathbf{0 . 0 0 1} \\
0.88 \\
0.99 \\
\mathbf{0 . 0 0 5}\end{array}$ \\
\hline Kelp weight (g) & $\begin{array}{l}\text { Intercept } \\
\text { Trawling[Impact] } \\
\text { Period[After] } \\
\text { Trawling } \times \text { Period }\end{array}$ & $\begin{array}{c}565.47 \\
-35.24 \\
52.03 \\
-278.27\end{array}$ & $\begin{array}{r}93.04 \\
142.58 \\
73.67 \\
127.63\end{array}$ & $\begin{array}{c}317 \\
9 \\
317 \\
317\end{array}$ & $\begin{array}{r}6.08 \\
-0.25 \\
0.71 \\
-2.18\end{array}$ & $\begin{array}{c}<\mathbf{0 . 0 0 1} \\
0.81 \\
0.48 \\
\mathbf{0 . 0 3}\end{array}$ \\
\hline
\end{tabular}

caused by trawling in the total number of juvenile Pollachius (pollack, saith) was found both in the trawl tracks and in the kelp margins, from $6.1 \pm 9.0$ to $1.5 \pm$ 1.1 in the trawl tracks and to $1.8 \pm 0.8$ in the marginal kelp forest surrounding the trawl tracks (Table 6). The number was $2.1 \pm 1.3$ in the first year and $2.6 \pm$ 2.3 in the second in the control area. A general reduction in the number of saithe occurred from the first to the second year, but the reduction was significantly larger in the control area compared to the trawled area after trawling, suggesting a positive effect of kelp trawling. Young saithe were observed in high abundances in the open trawl tracks. When regarding echosounder diagrams, RUV and cage data jointly, juvenile saithe using the water column above the canopy hardly seemed to be affected by trawling tracks, but they changed their vertical distribution, being distributed vertically all the way down to the sea floor after trawling.

There was a significant decrease in the number of adult pollack in the trawl area after trawling $(2.1 \pm$ 1.9 in the trawl tracks and $1.7 \pm 0.4$ in the marginal

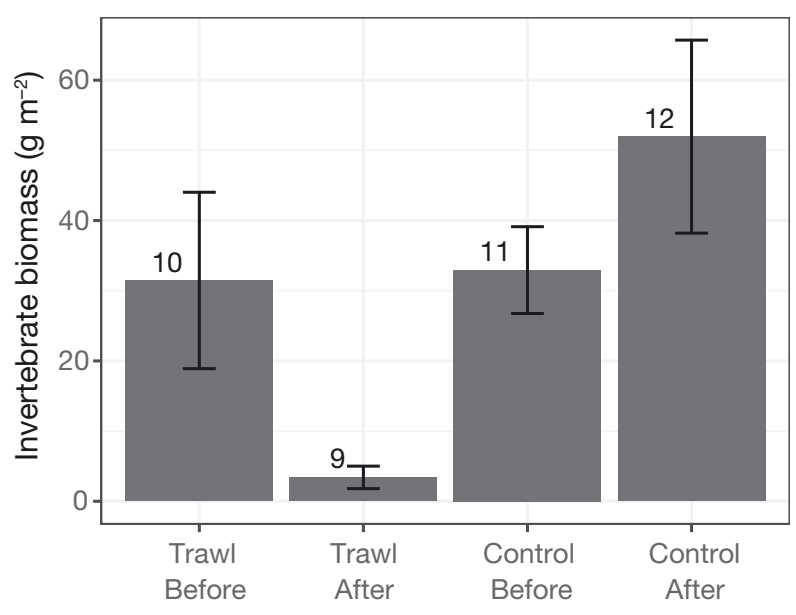

Fig. 4. The biomass of invertebrates $\left(\mathrm{g} \mathrm{m}^{-2}\right)$ living on epiphytes on kelp stipes at trawled and control stations before and after kelp trawling. Error bars are $\pm \mathrm{SE}_{i}$ number of replicates is given above bars

kelp forest) compared to before in the intact forest (10.4 \pm 9.5; Table 6). Both cod and pollack cruised through the kelp forest under the canopy in the RUV 
Table 3. Results from generalized linear mixed models comparing biomass ( $\mathrm{g}$ of invertebrate fauna per $\mathrm{m}^{2}$ ) in the trawled and control area before (September 2017) and after (September 2018) kelp trawling. Model coefficients ( $\beta$ ), standard error (SE), degrees of freedom (DF), $t$ (Gaussian distribution models) and p-values are shown. Significance on a 0.05 level is indicated by bold text

\begin{tabular}{|lrcccc|}
\hline Term & $\beta$ & $\mathrm{SE}(\beta)$ & $\mathrm{DF}$ & $t$ & $\mathrm{p}$ \\
\hline Intercept & 31.4 & 13.0 & 29 & 2.41 & 0.02 \\
Trawling[Impact] & 0.52 & 18.8 & 9 & 0.03 & 0.98 \\
Period[After] & 23.1 & 14.3 & 29 & 1.62 & 0.12 \\
Trawling $\times$ Period & -58.8 & 19.9 & 29 & -2.96 & $\mathbf{0 . 0 0 6}$ \\
\hline
\end{tabular}

recordings. Trawling was associated with a significant decrease in the number of two-spotted gobies in the kelp margins (from $11.2 \pm 10.8$ to $1.8 \pm 2.7$ ), but no significant effect was found in the trawl tracks $(20.5 \pm$ 27.6 after trawling).

\subsection{Trophic relationships and ecosystem structure}

Many examined stomachs were empty ( $44 \%$ in 2017 and $43 \%$ 2018), and for all species, a substantial part of the stomach contents could not be identified. The contents that could be identified showed that cod mainly fed on decapods (Cancer pagurus, hermit crabs, Galathea sp.) and other fish, and goldsinny wrasse mainly fed on gastropods (e.g. Ansates pellucida, Rissoa parva), which are associated with epiphytes on kelp stipes. Longspined bullhead mainly fed on different crustaceans, saithe on decapods and gastropods, shorthorn sculpin on other fish, and 3bearded rockling preyed on decapods and fish.

\section{DISCUSSION}

The directed kelp trawling used as a large-scale experimental disturbance had a strong impact on the kelp forest ecosystems in the study area. It represented an acute disruption, which altered the physical kelp forest structure and affected 4 trophic levels, from primary producers to secondary producers and 2 levels of predatory fish. The effect was negative on low trophic levels and variable on higher trophic levels. Both positive and the most negative effects were found in higher trophic levels and could be linked to how different species used the individual kelps and the forest structure.

By removing $26 \%$ of the canopy-forming mature kelp plants, the disturbance created large openings

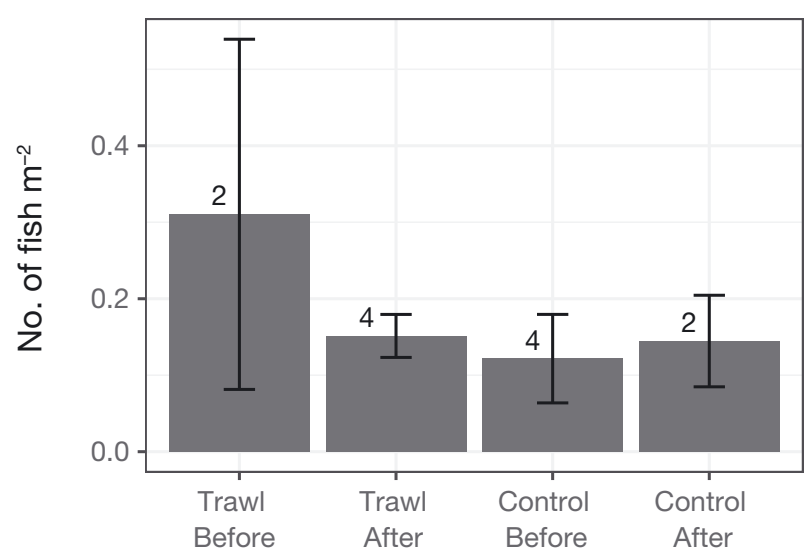

Fig. 5. Densities of fish (ind. $\mathrm{m}^{-2}$ ) above the kelp canopy estimated from echograms in trawled and control stations before and after kelp trawling. Error bars are $\pm \mathrm{SE}$; number of replicates is given above bars

in the dense forest, which changed the kelp forest structure and its function as a macrohabitat. An $\sim 46 \%$ reduction in the total abundance of fish living under the canopy was observed at trawled stations from RUVs (Fig. 7), but with interspecific differences that may correspond to habitat usage (Perez-Matus \& Shima 2010). Loss of canopy cover will decrease light attenuation, which has consequences for shadeadapted understory algae, as well as for fauna and fish relying on the canopy for shelter (Bodkin 1988, Toohey et al. 2004). The consequent $67 \%$ reduction in total amount of epiphytes per $\mathrm{m}^{2}$ associated with the loss of old plants inside the trawl tracks represents an additional loss of microhabitat. The invertebrates living on the epiphytes are the main prey for fish associated with the kelp forest (Schultze et al. 1990, Christie et al. 2003, Edgar \& Aoki 1993, Norderhaug et al. 2005, stomach contents from the present study). Based on the biomass of these animals, this implies a reduction of $89 \%$ of invertebrates per $\mathrm{m}^{2}$. The loss of microhabitats and prey are important properties of the kelp forest as a nursery area that

Table 4. Results from the generalized linear mixed model (Gaussian distribution), showing differences in fish densities above the kelp canopy from echograms before (September 2017) and after (September 2018) kelp trawling and compared to control stations. Test statistics for $\beta$, standard error

(SE), degrees of freedom (DF), $t$ and $\mathrm{p}$-values are shown

\begin{tabular}{|lrccrc|}
\hline Term & $\beta$ & $\mathrm{SE}(\beta)$ & $\mathrm{DF}$ & \multicolumn{1}{c|}{$t$} & $\mathrm{p}$ \\
\hline Intercept & 0.226 & 0.109 & 7 & 2.075 & 0.08 \\
Trawling[Impact] & -0.055 & 0.133 & 7 & -0.411 & 0.69 \\
Period[After] & -0.073 & 0.136 & 1 & -0.538 & 0.69 \\
Trawling $\times$ Period & 0.025 & 0.167 & 1 & 0.152 & 0.90 \\
\hline
\end{tabular}



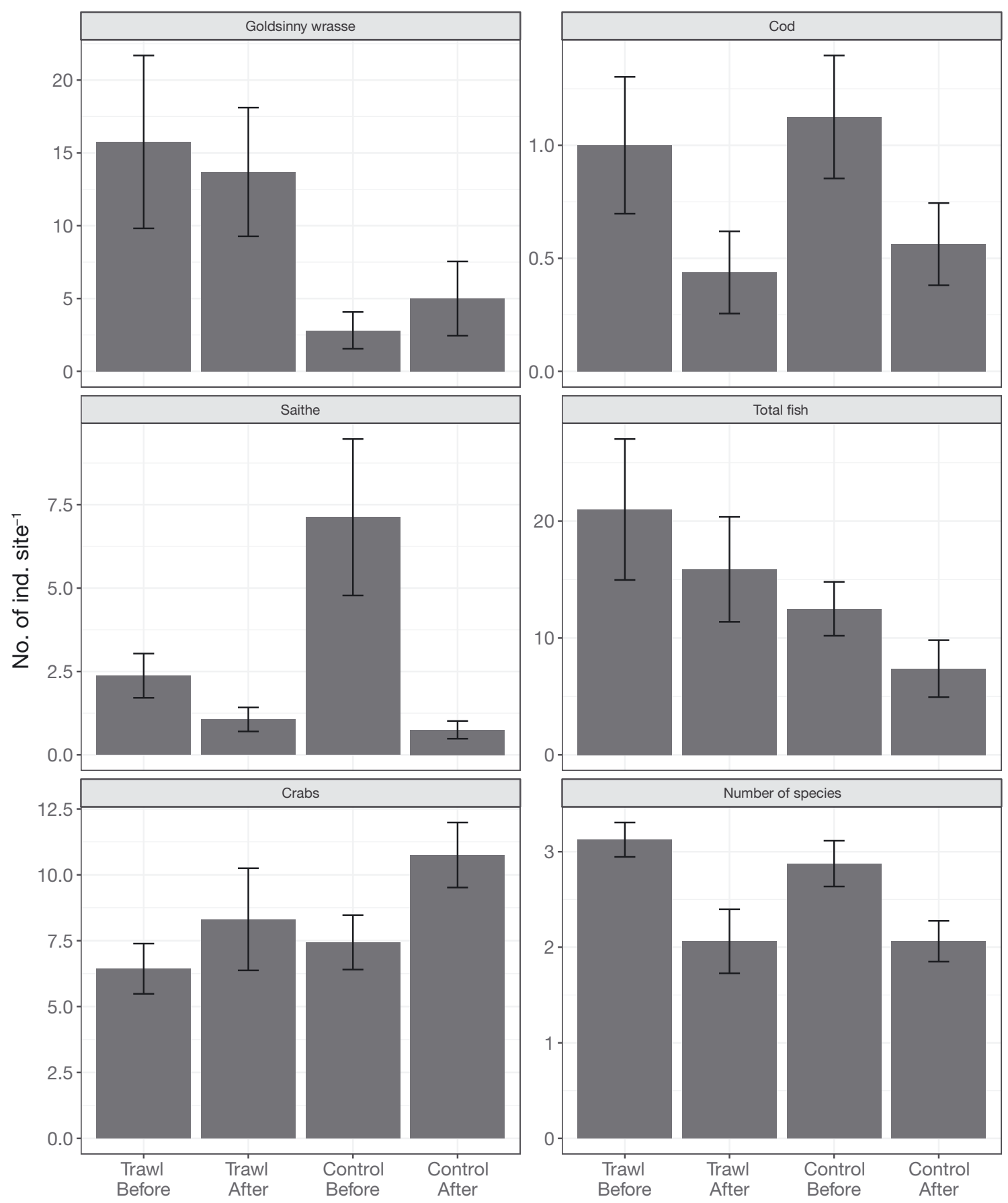

Fig. 6. Mean $( \pm \mathrm{SE})$ number of individuals caught in the fish and crab cages per site, before and after kelp trawling and compared to the control area. Number of replicates (sites) in each area was 16 per year. Values are shown for goldsinny wrasse, cod, saithe, total number of fish, total number of crabs and total number of species per site

likely explains the corresponding strong reduction in abundances of juvenile Pollachius spp. (by some $75 \%$ ). Our findings are consistent with small-scale experiments by Perez-Matus \& Shima (2010) showing negative responses for small fish from a reduction in habitat heterogeneity, and variable responses of larger fish to larger-scale habitat density. Research from other areas on the effects of reduced canopy cover on fish assemblages show mixed responses. Loss of kelp canopy has been shown to increase abundances of juvenile fish (Levin 1993), and increase schools of adult Gadidae fish, but reduce 
Table 5. Results from generalized linear mixed models (Poisson and negative binomial distribution) on differences in cage catches per site for goldsinny wrasse, cod, saithe, the total number of fish, crabs and total number of species per site before and after kelp trawling and compared to the control area. Test statistics for $\beta$ and corresponding standard error (SE), $z$ and p-values are shown. Significance on a 0.05 level is indicated by bold text

\begin{tabular}{|c|c|c|c|c|c|}
\hline Response & Term & $\beta$ & $\mathrm{SE}(\beta)$ & $z$ & $\mathrm{p}$ \\
\hline \multirow[t]{4}{*}{ Goldsinny wrasse } & Intercept & -0.99 & 0.74 & -1.34 & 0.18 \\
\hline & Trawling[Impact] & 2.23 & 0.94 & 2.37 & 0.02 \\
\hline & Period[After] & 0.58 & 0.19 & 3.09 & 0.002 \\
\hline & Trawling x Period & -0.72 & 0.21 & -3.44 & $<0.001$ \\
\hline \multirow[t]{4}{*}{ Cod } & Intercept & 0.06 & 0.27 & 0.23 & 0.82 \\
\hline & Trawling[Impact] & -0.12 & 0.37 & -0.33 & 0.74 \\
\hline & Period[After] & -0.69 & 0.41 & -1.70 & 0.09 \\
\hline & Trawling x Period & -0.13 & 0.61 & -0.22 & 0.83 \\
\hline \multirow{4}{*}{ Saithe } & Intercept & 1.43 & 0.27 & 5.30 & $<0.001$ \\
\hline & Trawling[Impact] & -0.85 & 0.39 & -2.16 & 0.03 \\
\hline & Period[After] & -2.25 & 0.30 & -7.42 & $<0.001$ \\
\hline & Trawling x Period & 1.45 & 0.42 & 3.44 & $<0.001$ \\
\hline \multirow[t]{4}{*}{ Total fish abundance } & Intercept & 2.39 & 0.24 & 10.04 & $<0.001$ \\
\hline & Trawling[Impact] & 0.29 & 0.33 & 0.87 & 0.38 \\
\hline & Period[After] & -0.67 & 0.25 & -2.65 & 0.008 \\
\hline & Trawling x Period & 0.34 & 0.34 & 0.99 & 0.32 \\
\hline \multirow[t]{4}{*}{ Crabs } & Intercept & 1.92 & 0.15 & 12.75 & $<0.001$ \\
\hline & Trawling[Impact] & -0.19 & 0.22 & -0.87 & 0.39 \\
\hline & Period[After] & 0.37 & 0.12 & 3.12 & 0.002 \\
\hline & Trawling x Period & -0.11 & 0.18 & -0.64 & 0.52 \\
\hline \multirow[t]{4}{*}{ Number of species } & Intercept & 1.06 & 0.15 & 7.16 & $<0.001$ \\
\hline & Trawling[Impact] & 0.08 & 0.20 & 0.41 & 0.68 \\
\hline & Period[After] & -0.33 & 0.23 & -1.46 & 0.15 \\
\hline & Trawling x Period & -0.08 & 0.32 & -0.26 & 0.78 \\
\hline
\end{tabular}

the abundance of juvenile demersal fish (Siddon et al. 2008), and both increase (Cole et al. 2012) and decrease fish diversity (Edgar et al. 2004) in relation to direct and indirect canopy effects and intraspecific and interspecific species interactions. Mixed responses in our study can also be related to the use of the kelp forest by different species.

The effect of kelp trawling on species (functional groups) on different levels in the kelp forest food web is summarized in Fig. 8. The figure also shows home range to indicate how different species use the kelp forest. The trawling effect was negative on the 2 lowest food web levels, including sessile species such as habitat-building kelp and epiphytic algae, as well as the small invertebrates with a small home range. Predators with a larger home range can escape or use the open patches created by trawling according to how they depend on prey associated with kelp, or use these habitats for shelter. This can explain the highly variable responses in higher trophic levels we found in the present study. Cancer crabs are predators more associated with the seafloor than the kelp vegetation itself, and commonly hide in crevices and under stones (Steneck et al. 2013). This may explain the lack of effect on the abundances of crabs. Goldsinny was closely associated with kelps for food and shelter, which likely explained their reduction in abundance after trawling. Saithe swam in the water column above the canopy and may be little affected by removal of kelp patches except for a redistribution throughout the water column. RUVs and stomach contents showed that pollack hunt under the kelp canopy, which could explain the dramatic and significant reduction in abundance after trawling. Stomach contents from pollack and cod collected during this study, combined with existing research, demonstrate that predatory fish species survive on a diverse diet of decapods and other fish, which do not necessarily only live in kelp forests (Wennhage \& Pihl 2002, Norderhaug et al. 2005, present study). Larger predatory fish also spend significant portions of their life cycle outside subtidal kelp forests, and when they do use these habitats it is over scales of several kilometers (Rogers et al. 2014), i.e. both inside and outside kelp forests. Species-specific responses from removing the canopy may also have arisen from the 

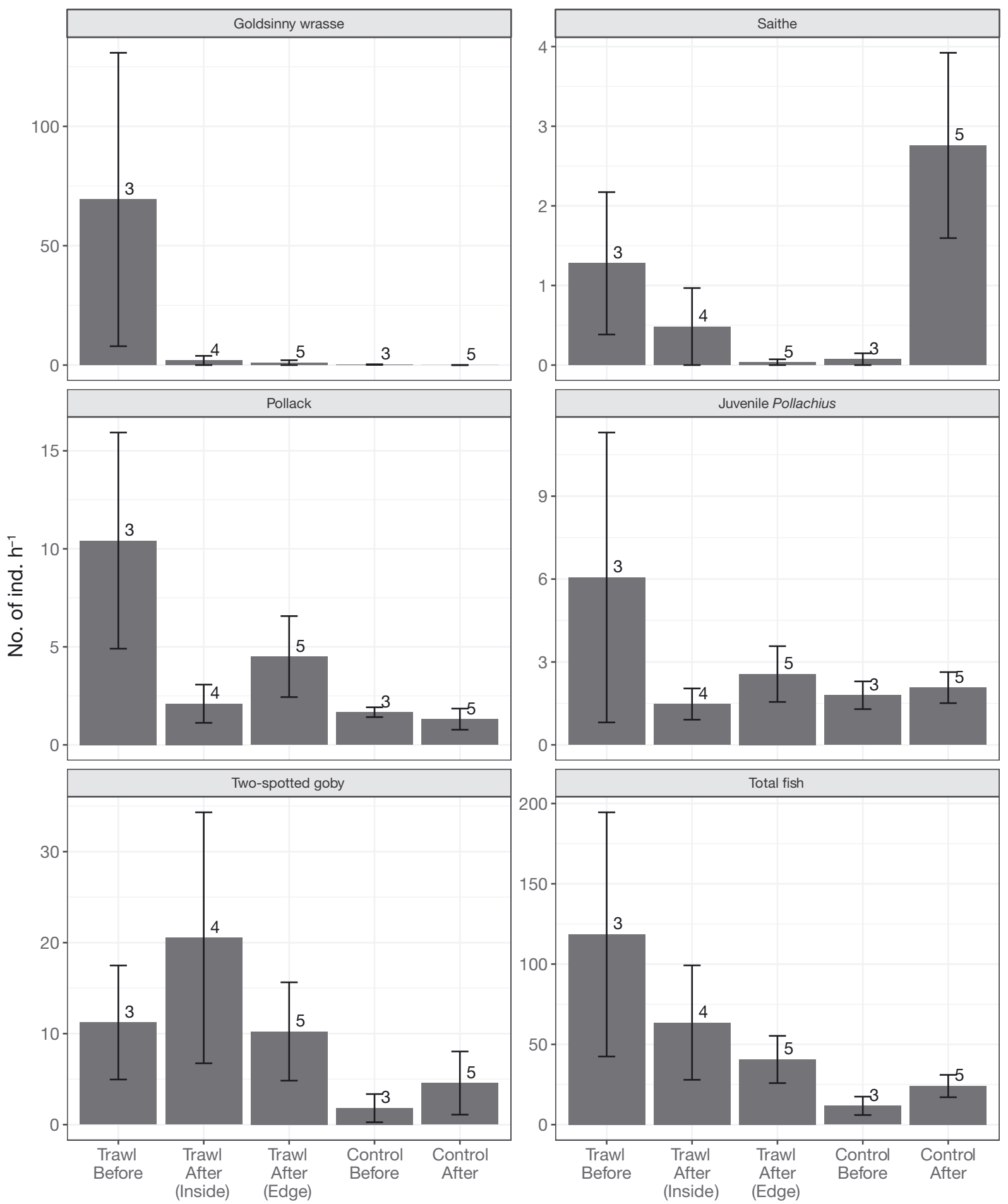

Fig. 7. Number of fish observed per hour (mean \pm SE) in the remote underwater videos (RUVs) in trawl stations (inside trawl track and along the trawl edge facing the kelp forest) and in control stations before and after trawling. The number of RUVs in each area is given above bars. Values are shown for goldsinny wrasse, cod, saithe, pollack, juvenile Pollachius (i.e. juvenile saithe and pollack $<16 \mathrm{~cm}$ ), two-spotted goby and the total number of fish

combined effects on both prey and the predator. RUVs facing the marginal kelp forests revealed edge effects and a significant reduction in abundances of pollack and small fish including juvenile Pollachius spp. and gobies. Marginal kelp forests have sparser canopies and increased light attenuation, and thereby 
Table 6. Results from generalized mixed effects models (Poisson and negative binomial distribution) used to compare the number of fish observed per $\mathrm{h}$ in the RUV videos from trawl tracks vs control (left) and edge effects i.e. RUVs in trawl tracks facing marginal surrounding kelp forest vs control (right). Results are shown for goldsinny wrasse, cod, saith, pollack, juvenile Pollachius (i.e. juvenile saithe and pollack $<16 \mathrm{~cm}$ ), two-spotted goby and the total number of fish. Test statistics for $\beta$, standard error (SE), $\mathrm{z}$ and $\mathrm{p}$ values are shown. For adult cod the model did not converge. Significance on a 0.05 level is indicated by bold text

\begin{tabular}{|c|c|c|c|c|c|c|c|c|c|}
\hline & \multirow[t]{2}{*}{ Term } & \multicolumn{4}{|c|}{ — Trawl track } & \multicolumn{4}{|c|}{ — Edge effects } \\
\hline & & $\beta$ & SE $(\beta)$ & Z & $\mathrm{p}$ & $\beta$ & $\mathrm{SE}(\beta)$ & $z$ & $\mathrm{p}$ \\
\hline \multirow{4}{*}{$\begin{array}{l}\text { Goldsinny } \\
\text { wrasse }\end{array}$} & Intercept & -33.08 & 110.10 & -0.30 & 0.76 & -28.83 & 0.01 & -2234 & $<0.001$ \\
\hline & Trawling[Impact] & 36.27 & 110.10 & 0.33 & 0.74 & 30.11 & 0.01 & 2329 & $<0.001$ \\
\hline & Period[After] & 31.73 & 110.11 & 0.29 & 0.77 & 23.34 & 0.01 & 1813 & $<0.001$ \\
\hline & Trawling $\times$ Period & -35.31 & 110.12 & -0.32 & 0.75 & -31.62 & 0.01 & -2446 & $<0.001$ \\
\hline \multirow[t]{4}{*}{ Saithe } & Intercept & -0.17 & 0.63 & -0.28 & 0.78 & -0.43 & 0.34 & -1.25 & 0.21 \\
\hline & Trawling[Impact] & -0.59 & 1.06 & -0.56 & 0.56 & -0.44 & 0.65 & -0.68 & 0.50 \\
\hline & Period[After] & -5.74 & 1 & -3.84 & $<0.001$ & -5.36 & 1 & -4.91 & $<0.001$ \\
\hline & Trawling $\times$ Period & 4 & 2 & 2.21 & 0.03 & -1 & 2 & -0.41 & 0.68 \\
\hline \multirow[t]{4}{*}{ Pollack } & Intercept & -1.48 & 0.66 & -2.24 & 0.03 & -1.04 & 0.60 & -1.74 & 0.08 \\
\hline & Trawling[Impact] & 2 & 0.97 & 1.64 & 0.10 & 2 & 0.85 & 2.78 & 0.005 \\
\hline & Period[After] & 0.20 & 0.46 & 0.44 & 0.66 & 0.67 & 0.81 & 0.83 & 0.41 \\
\hline & Trawling $\times$ Period & -2.73 & 0.56 & -4.90 & $<0.001$ & -5.10 & 1.19 & -4.30 & $<0.001$ \\
\hline \multirow{4}{*}{$\begin{array}{l}\text { Juvenile } \\
\text { Pollachius }\end{array}$} & Intercept & -0.81 & 0.54 & -1.50 & 0.13 & -0.57 & 0.43 & -1.32 & 0.19 \\
\hline & Trawling[Impact] & 0.51 & 0.84 & 0.61 & 0.54 & 1.35 & 0.62 & 2.17 & 0.03 \\
\hline & Period[After] & -0.86 & 0.48 & -1.80 & 0.07 & -0.88 & 0.65 & -1.37 & 0.17 \\
\hline & Trawling $\times$ Period & -1.73 & 0.61 & -2.84 & 0.005 & -3.06 & 0.91 & -3.36 & 0.001 \\
\hline \multirow{4}{*}{$\begin{array}{l}\text { Two-spotted } \\
\text { goby }\end{array}$} & Intercept & -0.06 & 1.05 & -0.06 & 0.95 & 0.10 & 1.21 & 0.09 & 0.93 \\
\hline & Trawling[Impact] & 1.43 & 1.39 & 1.03 & 0.30 & 1.26 & 1.53 & 0.83 & 0.41 \\
\hline & Period[After] & 0.39 & 0.98 & 0.40 & 0.69 & 0.37 & 1.06 & 0.35 & 0.72 \\
\hline & Trawling $\times$ Period & -0.27 & 1.60 & -0.17 & 0.87 & -4.29 & 1.80 & -2.38 & 0.02 \\
\hline \multirow{4}{*}{$\begin{array}{l}\text { Total fish } \\
\text { abundance }\end{array}$} & Intercept & 2.08 & 0.53 & 3.93 & $<0.001$ & 2.08 & 0.49 & 4.23 & $<0.001$ \\
\hline & Trawling[Impact] & 2 & 0.86 & 1.94 & 0.05 & 2 & 0.79 & 2.09 & 0.04 \\
\hline & Period[After] & 0.23 & 0.75 & 0.31 & 0.76 & 0.23 & 0.69 & 0.33 & 0.74 \\
\hline & Trawling $\times$ Period & -1.23 & 1.16 & -1.06 & 0.29 & -4.76 & 1.12 & -4.24 & $<0.001$ \\
\hline
\end{tabular}

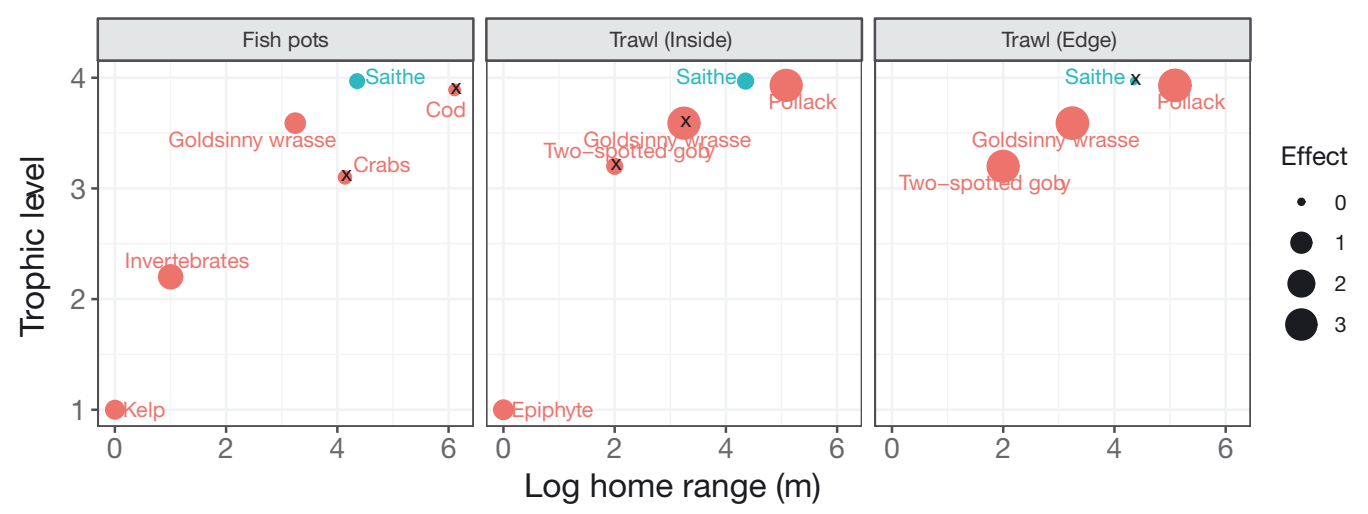

Fig. 8. The effect of kelp trawling on species (functional groups) on different levels in the food web and according to (log) home range, from fish pots (left) as well as remote underwater videos (RUVs) in the trawl tracks (middle) and facing the marginal kelp forest (trawl edge, right). The bubble size shows effect as \% increase (blue) or decrease (red) in the trawled area minus the \% change in the control area. Trophic levels were obtained for small invertebrates from Norderhaug \& Christie (2011), Cancer pagurus from www.sealifebase.se, two-spotted goby from www.fishbase.se, and other fish species from stomach contents (present study). Home ranges for invertebrates are from Norderhaug et al. (2002), C. pagurus from Skajaa et al. (1998), two-spotted goby from www.marlin.ac.uk and Wacker et al. (2012), goldsinny from Hilldén (1981), Collins (1996) and Aasen (2019), cod from Espeland et al. (2007) and Aalvik et al. (2015), saithe from Rangeley \& Kramer (1995) and pollack from Winge (2018). Very few goldsinny were observed on RUVs in the control area before trawling, producing spurious numbers; therefore, their bubble size is represented as the biggest size in the figure for illustration purposes only 
increase the visibility of both predatory and prey fish. The open trawl tracks provide limited shelter for both prey and predatory fish. This may explain the different responses in abundance of gobies in open trawled tracks and in marginal kelp forests. Edge effects are known to alter abundances of large predators in terrestrial forests (Brodie et al. 2015) and to cause accumulation of fish larvae on kelp forest margins in Argentina (Bruno et al. 2018).

Natural variability is a striking feature of this ecosystem, as shown by high interannual variability in both study areas. This variability can be attributed to environmental conditions such as seasonal timing and temperature, disturbances such as storms, and biological variability such as year class strength of different species (Witman \& Dayton 2001, Christie et al. 2003, Connell 2007, Bekkby et al. 2014). Kelp forests are generally resilient systems (Smale \& Vance 2016, O'Leary et al. 2017). In Norwegian L. hyperborea kelp forests, removal of the canopy increases growth rates of the understory kelp and, consequently, the kelp biomass can recover quickly, in 3-4 yr (Steen et al. 2016). Epiphytic algae do not develop on kelp stipes until the kelps become large and the stipes develop a rough surface suitable for attachment. Consequently, it takes 6 or more years for the epiphytes and the mobile fauna inhabiting the epiphytes to recover (Christie et al. 1994, Norderhaug et al. 2012). These past studies and our current findings suggest that the function of the habitat as a feeding and nursery ground for fish will be reduced for 6 yr or longer following removal. Recovery rates for the ecosystem were not part of the present study, but are expected to decrease with trophic level (e.g. the kelps recovering faster than the associated primary and secondary consumers, and fish recovering only after these food sources become available again). In a future warmer climate, the recovery capacity and rate will also depend on the physiological response of kelps to warming, since the recovery rate in part depends on kelp growth rate (Wernberg et al. 2010). Kelp forest resilience and how it is affected by climate change and other human impacts should be taken into account when making decisions to commercially harvest kelp, for example, by using trawling strategies that only remove a portion of the kelp biomass and leave areas with pristine forests dominated by old kelps and abundant epiphytes to keep the ecosystem functions of kelp forests intact. Fish communities should also be monitored in harvested areas to track the effects of altered habitat to higher trophic levels.

Natural disturbances are challenging to predict and to test experimentally, and so studies such as ours, combined with insights from large clearing experiments, are useful to understand the impacts of increased disturbance regimes in kelp forests. Natural disturbances are expected to effect kelp forests in similar ways to trawling by removing patches of kelp canopy. Therefore, our findings provide insight into possible consequences of increased natural disturbances on the functioning of this ecosystem. Larger storms can disrupt the kelp forest structure and create open patches (Ebeling et al. 1985, Connell \& Irving 2008, Filbee-Dexter \& Scheibling 2012). Both strong storms and trawling are expected to remove kelp more effectively on flat open seafloor and tend to be most severe in shallow compared to deeper waters, due to more efficient trawling and higher wave exposure in these areas (wave forces decrease with depth: Directorate of Fisheries trawling statistics). However, the fact that kelp was removed in corridors by trawls may have created more edge effects from trawling compared to natural disturbances and could influence how fauna use these disturbed habitats. Vessels operation is restricted to 3-20 m depth and our study was consequently limited to this depth range. Storm removal of kelp can occur all year round, but with highest frequency during autumn storms. But since kelp needs several years to recover (Steen et al. 2016), the seasonal timing of the trawling was expected to have little importance for our study.

The effects from expected future disturbance intensity and frequency have been explored through structural equation modeling (SEM) by Byrnes et al. (2011) in a study on Californian giant kelp systems. In line with Byrnes et al. (2011), we found a reduction in community complexity (kelp structure and epiphytic amount) if disturbance intensity and frequency increased. Using scenario modelling, Byrnes et al. (2011) showed how increased storm frequency may decrease ecosystem diversity because slowly recolonizing species became extinct. The SEM models also predicted that perturbations would track up the food web with increasing effects on higher levels. The variable effects on higher trophic levels in our study is therefore only partly consistent with predictions by Byrnes et al. (2011) and with general patterns in other ecosystems of higher trophic level species being more susceptible to habitat loss and fragmentation than lower trophic levels (Gilbert et al. 1998). Our results from a single disturbance event suggest that cascading effects are more consistent on lower than higher food web levels, but also indicate the potential for stronger cascading effects through the ecosystem, especially if the disturbance intensity and frequency increased. 
In addition to being among the first experimental disturbance studies on a scale relevant for kelp-forest-associated fish, our study illustrates how different sampling techniques used in combination can provide a more complete picture of the responses within the fish assemblage than each technique alone. Fish cages catch actively foraging fish, RUVs quantify fish swimming under the canopy and echosounders quantify fish above the canopy. Bottom-mounted and upward-facing echosounders have been shown to be useful for fish studies at fixed stations (Kaartvedt et al. 2009), but to our knowledge, have never been used to study fish assemblages associated with kelp vegetation. Here, this tool provided an opportunity to perform non-intrusive assessments of fish assemblages in the water column. Importantly, the change in vertical distribution of saithe could only be fully understood when regarding data from the different sampling devices together.

In conclusion, our results show that large-scale experimental kelp trawling has ecological consequences that extend beyond the decline of the habitat-forming species to affect multiple trophic levels of the broader ecosystem. These effects include direct removal of food, diminished biogenic structure and indirect effects via altered fish assemblages across 4 ecosystem levels. Our findings also provide insights into the consequences of the increasing disturbance regimes predicted with climate change, such as increasing storm frequency and severity, which could create similar patterns of kelp loss and habitat fragmentation, and therefore lead to similar ecological consequences. Human disturbance such as kelp trawling may also amplify the effects of these new disturbance regimes by decreasing the resilience of ecosystems and making them more vulnerable to naturally occurring events such as storms (Ling et al. 2015). We suggest that management of coastal ecosystems should, consequently, focus on strengthening resilience and functional redundancy. Resilient ecosystems with high functional redundancy will be vital in order to withstand a future regime with increased disturbance frequency and intensity.

Acknowledgements. We thank Rolf Korneliussen, Gavin Macaulay and Egil Ona for valuable help and patience during echogram analysis. We thank Professor Stein Kaartvedt at the University of Oslo for encouraging the use of echosounders to count fish in dense kelp forest when few others believed in the idea. We also thank Amieroh Abrahams for advice on data presentation. This study could not have been performed without the industry. We thank Dupont for performing research trawling of kelp according to our instructions. We also thank the Ministry of Trade, Industry and Fisheries for funding the project. Last but not least, we thank the friendly and helpful staff at Nordøyan for great service and also local fishermen for sharing their experience with us.

\section{LITERATURE CITED}

Aalvik IM, Moland E, Olsen EM, Stenseth NC (2015) Spatial ecology of coastal Atlantic cod Gadus morhua associated with parasite load. J Fish Biol 87:449-464

Aasen NJ (2019) The movement of five wrasse species (Labridae) on the Norwegian west coast. MSc thesis, University of Oslo

*Bates D, Mächler M, Bolker BM, Walker SC (2015) Fitting linear mixed-effects models using lme4. J Stat Softw 67: $1-48$

*Bekkby T, Rinde E, Gundersen H, Norderhaug KM, Gitmark JK, Christie H (2014) Length, strength and water flow: relative importance of wave and current exposure on morphology in kelp Laminaria hyperborea. Mar Ecol Prog Ser 506:61-70

*Bennett WG, Begossi A, Cundill G, Díaz S and others (2015) Linking biodiversity, ecosystem services, and human well-being: three challenges for designing research for sustainability. Curr Opin Environ Sustain 14:76-85

Bodkin JL (1988) Effects of kelp forest removal on associated fish assemblages in central California. J Exp Mar Biol Ecol 117:227-238

Bodvin T, Steen H, Moy FE (2014) Effekter av tarehøsting på fisk og skalldyr i Vikna, Nord-Trøndelag, 2013 (in Norwegian with English summary). IMR Report 38:1-26

Brodie JF, Giordano AJ, Ambu L (2015) Differential responses of large mammals to logging and edge effects. Mamm Biol 80:7-13

* Bruno DO, Victorio MF, Acha EM, Fernández DA (2018) Fish early life stages associated with giant kelp forests in sub-Antarctic coastal waters (Beagle Channel, Argentina). Polar Biol 41:365-375

* Buschmann AH, Camus C (2019) An introduction to farming and biomass utilisation of marine macroalgae. Phycologia 58:443-445

*Brnes JE, Reed DC, Cardinale BJ, Cavanaugh KC, Holbrook SJ, Schmitt RJ (2011) Climate driven increases in storm frequency simplify kelp forest food webs. Glob Change Biol 17:2513-2524

Christie H, Rinde E, Fredriksen S, Skadsheim A (1994) Økologiske konsekvenser av taretråling: Restituering av tareskog, epifytter og hapterfauna etter taretråling ved Rogalandskysten (in Norwegian with English abstract). NINA Report 295:1-29

* Christie H, Jørgensen NM, Norderhaug KM, WaageNielsen E (2003) Species distribution and habitat exploitation of fauna associated with kelp (Laminaria hyperborea) along the Norwegian coast. J Mar Biol Assoc UK 83:687-699

Clark RP, Edwards MS, Foster MS (2004) Effects of shade from multiple kelp canopies on an understory algal assemblage. Mar Ecol Prog Ser 267:107-119

* Cole RG, Davey NK, Carbines GD, Stewart R (2012) Fish-habitat associations in New Zealand: geographical contrasts. Mar Ecol Prog Ser 450:131-145

Collins KJ (1996) The territorial range of goldsinny wrasse on a small natural reef. In: Sayer MDJ, Treasurer JW, Costello MJ (ed) Wrasse: biology and use in aquaculture. Blackwell Scientific Publications, Oxford, p 61-69 
Connell SD (2007) Subtidal temperate rocky habitats: habitat heterogeneity at local to continental scales. In: Connell SD, Gillanders BM (eds) Marine Ecology. Oxford University Press, Melbourne, p 378-401

Connell SD, Irving AD (2008) Integrating ecology with biogeography using landscape characteristics: a case study of subtidal habitat across continental Australia. J Biogeogr 35:1608-1621

* Dayton PK, Currie V, Gerrodette T, Keller BD, Rosenthal R, Tresca DV (1984) Patch dynamics and stability of some California kelp communities. Ecol Monogr 54:253-289

* Dudgeon S, Petraitis PS (2001) Scale-dependent recruitment and divergence of intertidal communities. Ecology 82: 991-1006

Duffy JE, Benedetti-Cecchi L, Trinanes JA, Muller-Karger FE and others (2019) Toward a coordinated global observing system for marine macroalgae. Front Mar Sci 6:317

Ebeling AW, Laur DR, Rowley RJ (1985) Severe storm disturbances and reversal of community structure in a southern California kelp forest. Mar Biol 84:287-294

Edgar GJ, Aoki M (1993) Resource limitation and fish predation: their importance to mobile epifauna associated with Japanese Sargassum. Oecologia 95:122-133

*Edgar GJ, Banks S, Fariña JM, Calvopiña M, Martínez C (2004) Regional biogeography of shallow reef fish and macro-invertebrate communities in the Galapagos archipelago. J Biogeogr 31:1107-1124

* Espeland $\mathrm{SH}$, Gundersen AF, Olsen EM, Knutsen $\mathrm{H}$, Gjøsæter J, Stenseth NC (2007) Home range and elevated egg densities within an inshore spawning ground of coastal cod. ICES J Mar Sci 64:920-928

*Filbee-Dexter K, Scheibling RE (2012) Hurricane-mediated defoliation of kelp beds and pulsed delivery of kelp detritus to offshore sedimentary habitats. Mar Ecol Prog Ser 455:51-64

Filbee-Dexter K, Scheibling RE (2014) Sea urchin barrens as alternative stable states of collapsed kelp ecosystems. Mar Ecol Prog Ser 495:1-25

* Gilbert F, Gonzalez A, Evans-Freke I (1998) Corridors maintain species richness in the fragmented landscapes of a microecosystem. Proc Biol Sci 265:577-582

*Hilldén NO (1981) Territoriality and reproductive behavior in the goldsinny, Ctenolabrus rupestris L. Behav Processes 6:207-221

Kaartvedt S, Røstad A, Klevjer TA, Staby A (2009) Use of bottom-mounted echo sounders in exploring behavior of mesopelagic fishes. Mar Ecol Prog Ser 395:109-118

Kennelly SJ, Underwood AJ (1993) Geographic consistencies of effects of experimental physical disturbance on understorey species in sublittoral kelp forests in central New South Wales. J Exp Mar Biol Ecol 168:35-58

Korneliussen RJ, Heggelund Y, Macaulay G, Patel D, Johnsen E, Eliassen IK (2016) Acoustic identification of marine species using a feature library. Methods Oceanogr 17:187-205

Krumhansl KA, Byrnes J, Okamoto D, Rassweiler A and others (2016) Global patterns of kelp forest change over the past half-century. Proc Nat Sci USA 113:13785-13790

Langlois T, Harvey E, Fitzpatrick B, Meeuwig JJ, Shedrawi G, Watson DL (2010) Cost-efficient sampling of fish assemblages: comparison of baited video stations and diver video transects. Aquat Biol 9:155-168

Levin PS (1993) Habitat structure, conspecific presence and spatial variation in the recruitment of a temperate reef fish. Oecologia 94:176-185
*Ling SD, Scheibling RE, Johnson CR, Rassweiler A and others (2015) Global regime-shift dynamics of catastrophic sea urchin overgrazing. Philos Trans B 370:20130269

*Norderhaug KM, Christie H (2011) Secondary production in a Laminaria hyperborea kelp forest and variation according to wave exposure. Estuar Coast Shelf Sci 95: 135-144

Norderhaug KM, Christie H, Rinde E (2002) Colonisation of kelp imitations by epiphyte and holdfast fauna; a study of mobility patterns. Mar Biol 141:965-973

*Norderhaug KM, Christie H, Fosså JH, Fredriksen S (2005) Fish-macrofauna interactions in a kelp (Laminaria hyperborea) forest. J Mar Biol Assoc UK 85:1279-1286

Norderhaug KM, Christie H, Fredriksen S (2007) Is habitat size an important factor for faunal abundances on kelp (Laminaria hyperborea)? J Sea Res 58:120-124

*Norderhaug KM, Christie H, Andersen GS, Bekkby T (2012) Does the diversity of kelp forest fauna increase with wave exposure? J Sea Res 69:36-42

* Norderhaug KM, Gundersen H, Pedersen A, Moy F and others (2015) Combined effects from climate variation and eutrophication on the diversity in hard bottom communities on the Skagerrak coast 1990-2010. Mar Ecol Prog Ser 530:29-46

${ }^{\prime}$ 'Leary JK, Micheli F, Airoldi F, Boch C and others (2017) The resilience of marine ecosystems to climatic disturbances. Bioscience 67:208-220

Perez-Matus A, Shima JS (2010) Disentangling the effects of macroalgae on the abundance of temperate reef fishes. J Exp Mar Biol Ecol 388:1-10

*Perry D, Staveley TAB, Gullström M (2018) Habitat connectivity of fish in temperate shallow water seascapes. Front Mar Sci 4:440-452

R Core Team (2018) R: a language and environment for statistical computing. R Foundation for Statistical Computing, Vienna, www.r-project.org

Rangeley RW, Kramer DL (1995) Use of rocky intertidal habitats by juvenile pollock Pollachius virens. Mar Ecol Prog Ser 126:9-17

* Rogers LA, Olsen EM, Knutsen H, Stenseth NC (2014) Habitat effects on population connectivity in a coastal seascape. Mar Ecol Prog Ser 511:153-163

* Schultze K, Janke K, Krüß A, Weidemann W (1990) The macrofauna and macroflora associated with Laminaria digitata and L. hyperborea at the island of Helgoland (German Bight, North Sea). Helgol Meeresunters 44:39-51

* Seidl R, Spies TA, Peterson DL, Stephens SL, Hicke JA (2016) Searching for resilience: addressing the impacts of changing disturbance regimes on forest ecosystem services. J Appl Ecol 53:120-129

* Siddon EC, Siddon CE, Stekoll MS (2008) Community level effects of Nereocystis luetkeana in southeastern Alaska. J Exp Mar Biol Ecol 361:8-15

พ Skajaa K, Fernö A, Løkkeborg S, Haugland EK (1998) Basic movement pattern and chemo oriented search towards baited pots in edible crab (Cancer pagurus L.). Hydrobiologia 371:143-153

* Smale DA (2020) Impacts of ocean warming on kelp forest ecosystems. New Phytol 225:1447-1454

* Smale DA, Vance T (2016) Climate-driven shifts in species' distributions may exacerbate the impacts of storm disturbances on North-east Atlantic kelp forests. Mar Freshw Res 67:65-74

* Smale DA, Burrows MT, Moore P, O'Connor N, Hawkins SJ (2013) Threats and knowledge gaps for ecosystem serv- 
ices provided by kelp forests: a northeast Atlantic perspective. Ecol Evol 3:4016-4038

Steen H, Moy FE, Bodvin T, Husa V (2016) Regrowth after kelp harvesting in Nord-Trøndelag, Norway. ICES J Mar Sci 73:2708-2720

Steneck R, Leland A, McNaught DC, Vavrinec J (2013) Ecosystem flips, locks, and feedbacks: the lasting effects of fisheries on Maine's kelp forest ecosystem. Bull Mar Sci 89:31-55

Teagle H, Hawkins SJ, Moore PJ, Smale DA (2017) The role of kelp species as biogenic habitat formers in coastal marine ecosystems. J Exp Mar Biol Ecol 492:81-98

Toohey B, Kendrick GA, Wernberg T, Phillips JC, Malkin S, Prince J (2004) The effects of light and thallus scour from Ecklonia radiata canopy on an associated foliose algal assemblage: the importance of photoacclimation. Mar Biol 144:1019-1027

Turner MG (2010) Disturbance and landscape dynamics in a changing world. Ecology 91:2833-2849

*Vásquez JA (2008) Production, use and fate of Chilean brown seaweeds: re-sources for a sustainable fishery. $\mathrm{J}$ Appl Phycol 20:457-467

Vea J, Ask E (2011) Creating a sustainable commercial harvest of Laminaria hyperborea, in Norway. J Appl Phycol 23:489-494

Wacker S, de Jong K, Forsgren E, Amundsen T (2012) Large males fight and court more across a range of social environments: an experiment on the two spotted goby Gobiusculus flavescens. J Fish Biol 81:21-34

Editorial responsibility: Laura Falkenberg (Guest Editor), Hong Kong, SAR

Reviewed by: 2 anonymous referees
Wennhage H, Pihl L (2002) Fish feeding guilds in shallow rocky and soft bottom areas on the Swedish west coast. J Fish Biol 61:207-228

*Wernberg T, Connell SD (2008) Physical disturbance and subtidal habitat structure on open rocky coasts: effects of wave exposure, extent and intensity. J Sea Res 59:237-248

*Wernberg T, Thomsen MS, Tuya F, Kendrick GA, Staehr PA, Toohey BD (2010) Decreasing resilience of kelp beds along a latitudinal temperature gradient: potential implications for a warmer future. Ecol Lett 13:685-694

* Wernberg T, Bennett S, Babcock R, de Bettignies T and others (2016) Climate-driven regime shift of a temperate marine ecosystem. Science 353:169-172

Wernberg T, Krumhansl K, Filbee-Dexter K, Pedersen MF (2019) Status and trends for the world's kelp forests. In: C Sheppard (ed) World seas: an environmental evaluation: ecological issues and environmental impacts. 2 edn, Vol 3. Academic Press, London, p 57-78

Winge AMM (2018) Fine scale spatial ecology of pollack (Pollachius pollachius) in a coastal environment assessed from acoustic elemetry. MSc thesis, University of Agder, Kristiansand

Witman JD, Dayton PK (2001) Rocky subtidal communities. In: Bertness MD, Gaines SD, Hay ME (eds) Marine community ecology. Sinauer Press, Sunderland, MA, p 339-366

* Zuur AF, Ieno EN (2016) A protocol for conducting and presenting results of regression-type analyses. Methods Ecol Evol 7:636-645

Submitted: January 14, 2020

Accepted: July 15, 2020

Proofs received from author(s): September 4, 2019 